\title{
ACCESS TO CARE FOR WOMEN DURING CHILDBIRTH IN UNIVERSITY HOSPITALS: CHARACTERIZATION AND ASSOCIATED FACTORS
}

\author{
Lorenna Viccentine Coutinho MONTESCHIO ${ }^{\mathrm{a}}$, Jenny Karol Gomes Sato SGOBERO ${ }^{\mathrm{b}}$, \\ Sonia Silva MARCONc, Thais Aidar de Freitas MATHIAS ${ }^{\mathrm{d}}$
}

\begin{abstract}
This study aimed to analyze the socioeconomic, demographic, obstetric, neonatal and healthcare factors associated with access to care by women during childbirth. It was a transversal study conducted on puerperal women in two university hospitals in the state of Paraná, Brazil in 2011. Access to childbirth was analyzed according to socioeconomic, demographic, obstetric, neonatal and healthcare variables. The puerperal women were interviewed during hospitalization, in the first 72 hours after birth. The data was analyzed by relative frequencies and calculation of the $\mathrm{x}^{2}$, considering a significant association when $\mathrm{p} \leq 0.05$. The overall rate of women referred to university hospitals was $17.7 \%$. A significant associated was found between access to childbirth and: residing in other cities; premature birth; underweight newborns; complications in the current pregnancy and the use of ambulances. It was concluded that the associated factors found in this study suggest that pregnant women with some risk required referral to university hospitals.
\end{abstract}

Descriptors: Perinatal care. Access to health services. Maternities.

\section{RESUMO}

O estudo teve por objetivo analisar os fatores socioeconômicos, demográficos, obstétricos, neonatais e assistenciais associados ao acesso da parturiente à assistência ao parto. Foi um estudo transversal, realizado com 310 puérperas em dois hospitais universitários do estado do Paraná, Brasil, em 2011. O acesso ao parto foi analisado segundo as variáveis socioeconômicas, demográficas, obstétricas, neonatais e assistenciais. As puérperas foram entrevistadas durante a internação no hospital, nas primeiras 72 horas após o parto. Os dados foram analisados por frequências relativas e cálculo do $x^{2}$, considerando-se associação significativa quando $p \leq 0,05$. A taxa total de mulheres encaminhadas aos hospitais universitários foi de 17,7\%. Encontrou-se associação significativa do acesso ao parto com: residir em outros municípios; parto prematuro; recém-nascido de baixo peso; intercorrências na gestação atual e uso de ambulância. Conclui-se que os fatores associados encontrados neste estudo sugerem que a gestante com algum risco necessitou de encaminhamento para os hospitais universitários.

Descritores: Assistência perinatal. Acesso aos serviços de saúde. Maternidades.

Título: Acesso de parturientes para a assistência ao parto em hospitais universitários: caracterização e fatores associados.

\section{RESUMEN}

El objetivo del estudio fue analizar los factores socioeconómicos, demográficos, obstétricos, neonatales y asistenciales relacionados con el acceso de las parturientas. Un estudio transversal que inchyó a 310 puérperas en dos hospitales universitarios en el estado de Paraná-Brasil en 2011. Acceso al parto se analizó de acuerdo a las variables socioeconómicas, demográficas, obstétricas, neonatales y asistenciales. Las mujeres fueron entrevistadas durante la estancia hospitalaria, las primeras 72 horas después del parto. Los datos analizados por frecuencias relativas y $x^{2}$, considerando asociación significativa cuando $p \leq 0,05$. La tasa total de mujeres encaminadas a los hospitales universitarios fue 17,7\%. Se encontró asociación significativa del acceso al parto, con: vivir en otros municipios, parto prematuro, recién nacido con bajo peso, complicaciones en el embarazo actual y el uso de ambulancia. Se concluye que los factores asociados encontrados sugieren que las mujeres embarazadas con algún riesgo requieren el encaminamiento a los hospitales universitarios.

Descriptores: Atención perinatal. Accesibilidad a los servicios de salud. Maternidades.

Título: Acceso de las parturientas para prestación de servicios en los hospitales universitarios: caracterización y factores asociados.

a Nurse. Master of Nursing from the Postgraduate Program in Nursing at the State University of Maringá (UEM), Maringá, Paraná, Brazil. b Nurse. Master of Nursing from the Postgraduate Program in Nursing at the State University of Maringá (UEM). Maringá, Paraná, Brazil.

c Nurse. Doctor of Nursing Philosophy. Undergraduate and Graduate Professor in Nursing at the State University of Maringá (UEM). Maringá, Paraná, Brazil.

d Nurse. Doctor of Public Health. Assistant Professor at the Nursing Department, Postgraduate Nursing Program at the State University of Maringá (UEM). Maringá, Paraná, Brazil. 


\section{INTRODUCTION}

Access to health care by pregnant women for hospital childbirth may be influenced by sociodemographic aspects or obstetric characteristics. The concept of access refers to the individual being admitted to the health system, but may also be defined in accordance with the final objective of the care and the results attained ${ }^{(1)}$.

The insufficiencies in Brazilian obstetric care relate not only to access but also the poor distribution of beds that results in long journeys by pregnant women seeking vacancies to give birth, exposing them to risks and aggravation of their situation $^{(2)}$.

The search for a hospital by pregnant women for childbirth and the healthcare at the first hospital sought after has been improving in the country, and the south region has better access indicators, given that it has been identified that $96 \%$ of women gave birth at the first hospital sought ${ }^{(3)}$. This index may give the false impression of a sufficient number of beds in the region, however, what is often observed is a disordered flow of pregnant women seeking healthcare at the reference units, which are often the units with greater complexity ${ }^{(4)}$.

Some studies on access to the hospital network at the time of birth have used the term "pilgrimage" to represent the path taken by women in search of healthcare. Therefore, the pilgrim represents women that have been unsuccessful in their attempts to seek healthcare ${ }^{(4-5)}$.

In the capital of the State of Maranhão, Brazil, it was verified that many women seek more than one health service and pass through at least two maternity wards in an attempt to seek assistance during childbirth, with lack of beds as the main reason for rejection ${ }^{(4)}$. In a study conducted in the city of Rio de Janeiro, Brazil, 36.6\% of pregnant adolescents had unsatisfactory access to childbirth, which was characterized by the mismatch between the place of residence and the place of birth. It was also verified that $20.7 \%$ of them did not give birth in the first hospital sought. Age, level of education, marital status, income and race/color were some factors that did not interfere with access ${ }^{(6)}$.

The city of residence is also a factor that can influence access, considering women differently if they live in cities other than that were the reference hospital for childbirth assistance is located. In a study conducted on all Brazilian cities, the distance between the place of residence and place of birth compromises geographical access, and constitutes a risk factor for child mortality ${ }^{(7)}$. In the same study, it was also observed that the characteristics of the city, such as population size and per capita income had an inverse relationship with geographical distance, i.e. the lower the population and income, the large the distance traveled for healthcare during childbirth $^{(7)}$.

Given the above, the analysis of access to hospitals by women during childbirth for healthcare may contribute to understanding the organization and weaknesses of public healthcare services for women in the pregnancy-puerperal cycle, as well as understanding how professional practices respond to the principles of integrality and problem-solving in healthcare ${ }^{(8)}$. Therefore, the present study aimed to analyze the socioeconomic, demographic, obstetric, neonatal and healthcare factors associated with access to healthcare by women during childbirth at two university hospitals in the state of Paraná, Brazil in 2011.

\section{METHODS}

A transversal study was conducted on puerperal women at two university hospitals in the State of Paraná, located in the cities of Maringá and Cascavel. The study included women attended to at the time of birth, during a month period, totaling 310 puerperal women. Eleven losses occurred owing to early discharges, before the pre-established period at the institutions, as well as refusal to participate in the study.

The data was collected in a 30 day period, during the month of December 2011, using a mixed questionnaire with open and closed questions, with 37 questions in total. The interviews were conducted mainly at the Maternity Wards at two university hospitals, however, they were also conducted at units in which women were hospitalized for the first 72 hours after birth, such as emergency rooms and obstetric centers, owing to a lack of room for hospitalization on the maternity wards.

The independent variables were the socioeconomic and demographic information, previous/current obstetric history, neonatal data and healthcare data. The age, marital status, race/color, level of education, city of residence and occupation were 
selected from the socioeconomic and demographic information. For the previous/current obstetric history and neonatal data variables, the type of birth, gestational age, weight of the newborn at birth and complications during the current pregnancy were selected. For the healthcare data, the reason for nonattendance or justification for referring the patient, method for traveling to the university hospital (car, tax, bus, ambulance and others) and the need for a vacancy at the neonatal ICU were analyzed.

The dependent variables in the study were access to childbirth and the city of residence. Access to childbirth was considered as receiving care at the first hospital sought. Two questions were asked for this: "Did you receive healthcare at the first hospital sought?" and "How many hospitals did you need to visit?". The city of residence was analyzed separately as a dependent variable, divided into the city where the university hospitals providing the care were located, or otherwise.

The program Excel ${ }^{\circledR}$ was used to tabulate the data and the software Statistica 7 was used for the descriptive statistical analysis. The test for association of the variables was chi-squared, considering $\alpha=5 \%$. The Odds Ratio $(\mathrm{OR})$ was used to measure the magnitude of the association between the variables.

The study was undertaken in accordance with that foreseen in resolution 196/96 from the National Research Ethics Commission - CONEP and the project was approved by the Committee for Research Ethics with Human Beings at the State University of Maringá, under report $\mathbf{n}^{\mathbf{0}}$ 657/2011. The women signed the Declaration of Free and Clarified Consent (TCLE), agreeing to participate in the study.

\section{RESULTS}

Characterization of the puerperal women, access to childbirth and associated factors

The average age of the women was $24.6 \pm$ 6.6 years and the majority was married $(86.1 \%)$ or had a stable union, and only $11.9 \%$ were single. It was verified that $48.4 \%$ considered themselves as white, $9.8 \%$ as black and $41.8 \%$ as mixed race. It was verified that $65.2 \%$ had not finished secondary education, $57.4 \%$ were housewives, $26.8 \%$ were registered salaried workers and $34.5 \%$ lived in cit- ies neighboring the two cities where the university hospitals in the study were located. More than half $(58.7 \%)$ had a vaginal birth and less than half $(43.2 \%)$ were primigravidae.

In relation to the birth conditions, the majority of births (82.3\%) occurred at 36 weeks of pregnancy or more, and 12.65 of newborns were born with a low weight, the majority of which $(87.2 \%)$ were transferred to neonatal ICU after birth.

$55(17.7 \%)$ of the puerperal women interviewed did not have adequate access, as they had to search for more than one hospital for assistance during childbirth (Table 1).

The city of residence was the only socioeconomic and demographic variable that presented an association with childbirth care (Table 1). Obstetric, healthcare and newborn variables showed an association with gestational age, weight at birth, complications during the current pregnancy and failure to receive care at the first hospital sought. Women who did not give birth at the hospital in their city of origin had six times the chance of being transported to a university hospital by ambulance than another means of transport (Table 1).

Differences were observed in the characteristics of the women according to the city of residence. Those living in the city other than where the university hospital was located had a higher percentage of adolescents $(p=0.016)$ as well as a higher percentage of those that did not concluded secondary education $(p<0.001)$. Approximately $45 \%$ of the women that did not live in the city where the university hospital was located were not attended to at the first service sought, contrasting with only $3.5 \%$ of the women residing in the said city $(p<0.001)$. Not residing in the city where the university hospital is located is associated with a preterm gestational age $(p=0.004)$ and the need for a space in the neonatal ICU, as $25.2 \%$ of women giving birth that resided outside of the city had premature newborns requiring neonatal ICU care $(15.9 \%)$. Living in another city is associated with transport via ambulance $(\mathrm{p}<0.001)$. This allows us to infer that such women were referred and transported safely to the reference hospitals (Table 2).

\section{Reasons for referral to another service}

In relation to the reasons for not receiving care during childbirth at the first service sought, few 
Table 1 - Distribution of puerperal women according to healthcare during birth and socioeconomic, demographic, obstetric, neonatal and healthcare variables. Maringá and Cascavel-PR, 2011.

\begin{tabular}{|c|c|c|c|c|c|c|}
\hline \multicolumn{7}{|c|}{ Healthcare for childbirth at the $1^{\text {st }}$ hospital sought } \\
\hline \multirow{2}{*}{ Variables } & \multicolumn{2}{|c|}{ Yes $(n=255)$} & \multicolumn{2}{|c|}{ No $(n=55)$} & \multirow[b]{2}{*}{ OR } & \multirow[b]{2}{*}{$p$-valor } \\
\hline & $\mathbf{N}$ & $\%$ & $\mathbf{N}$ & $\%$ & & \\
\hline \multicolumn{7}{|l|}{ Age (years) } \\
\hline$<20$ & 66 & 78.6 & 18 & 21.4 & 1.4 & 0.432 \\
\hline $20-35$ & 170 & 83.3 & 34 & 16.7 & & \\
\hline$>35$ & 19 & 86.4 & 3 & 13.6 & 0.8 & 0.715 \\
\hline \multicolumn{7}{|c|}{ Secondary Education Concluded } \\
\hline Yes & 93 & 86.1 & 15 & 13.9 & & \\
\hline No & 162 & 80.2 & 40 & 19.8 & 1.5 & 0.194 \\
\hline \multicolumn{7}{|l|}{ Marital status } \\
\hline Married/living together & 223 & 83.5 & 44 & 16.5 & & \\
\hline Single/divorced & 32 & 74.4 & 11 & 25.6 & 1.7 & 0.147 \\
\hline \multicolumn{7}{|l|}{ Occupation } \\
\hline Paid work & 110 & 83.3 & 22 & 16.7 & & \\
\hline Housewife & 145 & 81.5 & 33 & 18.5 & 1.1 & 0.669 \\
\hline \multicolumn{7}{|l|}{ Race/color } \\
\hline White & 123 & 82.0 & 27 & 18.0 & & \\
\hline Black/mixed race & 132 & 82.5 & 28 & 17.5 & 1.0 & 0.929 \\
\hline \multicolumn{7}{|l|}{ City of residence } \\
\hline Location of hospital & 196 & 96.6 & 7 & 3.4 & & \\
\hline Other & 59 & 55.1 & 48 & 44.9 & 22.8 & $<0.001$ \\
\hline \multicolumn{7}{|l|}{ No. of pregnancies } \\
\hline Multigravida & 147 & 83.5 & 29 & 16.5 & & \\
\hline Primigravida & 108 & 80.6 & 26 & 19.4 & 1.2 & 0.504 \\
\hline \multicolumn{7}{|c|}{ Complications during pregnancy* } \\
\hline No & 138 & 87.3 & 20 & 12.7 & & \\
\hline Yes & 116 & 76.8 & 35 & 23.2 & 2.1 & 0.016 \\
\hline \multicolumn{7}{|l|}{ Type of birth } \\
\hline Vaginal & 148 & 81.3 & 34 & 18.7 & & \\
\hline Cesarean & 107 & 83.6 & 21 & 16.4 & 0.9 & 0.605 \\
\hline \multicolumn{7}{|l|}{ Gestational age (weeks)* } \\
\hline 37 or more & 218 & 84.5 & 40 & 15.5 & & \\
\hline 27 to 36 & 36 & 70.6 & 15 & 29.4 & 2.3 & 0.018 \\
\hline \multicolumn{7}{|c|}{ Weight of newborn at birth (g) } \\
\hline Greater or equal to 2500 & 229 & 84.5 & 42 & 15.5 & & \\
\hline Less than 2500 & 26 & 66.7 & 13 & 33.3 & 2.7 & 0.006 \\
\hline \multicolumn{7}{|l|}{ Transport for childbirth } \\
\hline Others & 204 & 90.3 & 22 & 9.7 & & \\
\hline Ambulance & 51 & 60.7 & 33 & 39.3 & 6.0 & $<0.001$ \\
\hline \multicolumn{7}{|l|}{ Did newborn require ICU } \\
\hline No & 230 & 83.3 & 46 & 16.7 & & \\
\hline Yes & 25 & 73.5 & 9 & 26.5 & 1.8 & 0.158 \\
\hline
\end{tabular}

Source: research data.

*Some responses ignored 
Table 2 -Distribution of puerperal women by city of residence according to socioeconomic, demographic, obstetric, neonatal and healthcare variable. Maringá and Cascavel-PR, 2011.

\begin{tabular}{|c|c|c|c|c|c|c|}
\hline \multicolumn{7}{|c|}{ City of residence } \\
\hline \multirow{2}{*}{ Variables } & \multicolumn{2}{|c|}{ Same as hospital $(n=107)$} & \multicolumn{2}{|c|}{ Other $(n=203)$} & \multirow{2}{*}{ OR } & \multirow{2}{*}{$p$-valor } \\
\hline & $\mathbf{N}$ & $\%$ & $\mathbf{N}$ & $\%$ & & \\
\hline \multicolumn{7}{|l|}{ Age (years) } \\
\hline$<20$ & 38 & 35.5 & 46 & 22.7 & 1.9 & 0.016 \\
\hline $20-35$ & 62 & 57.9 & 142 & 69.9 & & \\
\hline$>35$ & 7 & 6.6 & 15 & 7.4 & 1.1 & 0.916 \\
\hline \multicolumn{7}{|c|}{ Secondary Education Concluded } \\
\hline Yes & 24 & 22.4 & 84 & 41.4 & & \\
\hline No & 83 & 77.6 & 119 & 58.6 & 2.4 & $<0.001$ \\
\hline \multicolumn{7}{|l|}{ Marital status } \\
\hline Married/living together & 87 & 81.3 & 180 & 88.7 & & \\
\hline Single/divorced & 20 & 18.7 & 23 & 11.3 & 1.8 & 0.074 \\
\hline \multicolumn{7}{|l|}{ Occupation } \\
\hline Paid work & 40 & 37.4 & 92 & 45.3 & & \\
\hline Housewife & 67 & 62.6 & 111 & 54.7 & 1.4 & 0.179 \\
\hline \multicolumn{7}{|l|}{ Race/color } \\
\hline White & 53 & 49.5 & 97 & 47.8 & & \\
\hline Black/mixed race & 54 & 50.5 & 106 & 52.2 & 0.9 & 0.769 \\
\hline \multicolumn{7}{|l|}{ City of residence } \\
\hline Location of hospital & 59 & 55.1 & 196 & 96.5 & & \\
\hline Other & 48 & 44.9 & 7 & 3.5 & 22.8 & $<0.001$ \\
\hline \multicolumn{7}{|l|}{ No. of pregnancies } \\
\hline Multigravida & 47 & 43.9 & 87 & 42.9 & & \\
\hline Primigravida & 60 & 56.1 & 116 & 57.1 & 1.0 & 0.857 \\
\hline \multicolumn{7}{|c|}{ Complications during pregnancy* } \\
\hline No & 51 & 47.7 & 107 & 52.7 & & \\
\hline Yes & 56 & 52.3 & 95 & 46.8 & 1.2 & 0.374 \\
\hline \multicolumn{7}{|l|}{ Type of birth } \\
\hline Vaginal & 63 & 58.9 & 119 & 58.6 & & \\
\hline Cesarean & 44 & 41.1 & 84 & 41.4 & 1.0 & 0.965 \\
\hline \multicolumn{7}{|l|}{ Gestational age (weeks) ${ }^{*}$} \\
\hline 37 or more & 80 & 74.8 & 178 & 87.7 & & \\
\hline 27 to 36 & 27 & 25.2 & 24 & 12.3 & 2.5 & 0.002 \\
\hline \multicolumn{7}{|c|}{ Weight of newborn at birth (g) } \\
\hline Greater or equal to 2500 & 89 & 83.2 & 182 & 89.7 & & \\
\hline Less than 2500 & 18 & 16.8 & 21 & 10.3 & 1.8 & 0.102 \\
\hline \multicolumn{7}{|l|}{ Transport for childbirth } \\
\hline Others & 49 & 45.8 & 177 & 87.2 & & \\
\hline Ambulance & 58 & 54.2 & 26 & 12.8 & 8.1 & $<0.001$ \\
\hline \multicolumn{7}{|l|}{ Did newborn require ICU } \\
\hline No & 90 & 84.1 & 186 & 91.6 & & \\
\hline Yes & 17 & 15.9 & 17 & 8.4 & 2.1 & 0.044 \\
\hline
\end{tabular}


women $(5.4 \%)$ reported that they did not know the reasons, some justifications were being primiparous $(5.4 \%)$ and not effectively being in labor (14.5\%). It is worth reiterating that in some cases, regardless of the pregnancy being high risk, the women were referred to due to the university hospital being a reference point for childbirth at the regional heath level, owing to the inexistence of hospitals or this type of care in the city of origin, as per the healthcare service flow (Table 3 ).

\section{Type of complications during pregnancy}

$40 \%$ of the puerperal women interviewed report at least one complication during pregnancy, with the most frequent being hypertensive (23.3\%) and urinary disturbances (22.6\%) (Table 4 ).

\section{DISCUSSION}

The percentage of women that did not give birth in the first hospital sought was $17.7 \%$. The reasons for not receiving healthcare at these hospitals, as reported by the women, were overall, the university hospital being a reference point, prematurity, lack of structure and lack of physicians. It was perceived in these reports that there is a flow of pregnant women in the direction of metropolises, which often overloads the healthcare network for childbirth in larger cities where there is a better healthcare structure ${ }^{(9)}$.

Table 3 - Reasons report for referral to the University Hospital. Maringá and Cascavel-PR, 2011.

\begin{tabular}{lcc}
\hline \multicolumn{1}{c}{ Justifications } & N & \% \\
\hline University hospital is a reference & 11 & 20.0 \\
point for care & 10 & 18.2 \\
Premature birth & 10 & 18.2 \\
Lack of structure for care during labor & 8 & 14.5 \\
Not in labor & 7 & 12.7 \\
No physician at the first service sought & 3 & 5.4 \\
First service does not cover the SUS & 3 & 5.4 \\
Being primiparous & 3 & 5.4 \\
Not known & $\mathbf{5 5}$ & $\mathbf{1 0 0}$ \\
\hline Total & &
\end{tabular}

Source: Research data.
In a study of antepartum "pilgrimages", the occurrence of rejection of care owing to the professional affirming that pregnant woman was not in labor may demonstrate that many women are unaware of when labor has started and the correct moment for seeking hospital care, especially primiparous women ${ }^{(4)}$, which represented $4.32 \%$ in this study. However, even being evaluated as such, the birth occurred at another service, which is incoherent with the reason for referral.

Some of the reasons cited by the women deserve attention, such as the fact of the first institution not covering care under the SUS, which demonstrates the difficulty of operating a reference maternity network to be sought at the time of birth.

In relation to the factors associated with healthcare during labor at the first hospital sought, a relationship was not verified between the social and economic variables, unlike previous studies in other Brazilian regions where race/color, age, income and marital status had an association with antepartum "pilgrimages"(4,9).

The city of residence was associated with receiving healthcare at the first hospital sought as women that lived in neighboring cities had to seek healthcare in their own city in order to then be referred to the university hospitals. In Cascavel

Table 4 - Distribution of complications during pregnancy reported by puerperal women, Maringá and Cascavel-PR, 2011.

\begin{tabular}{lcc}
\hline \multicolumn{1}{c}{ Complication } & N & \% \\
\hline Hypertensive disturbances & 34 & 23.3 \\
Urinary disturbances & 33 & 22.6 \\
Pain (lumbar or pelvic) & 19 & 13.0 \\
Bleeding & 14 & 9.6 \\
Placenta previa & 13 & 8.9 \\
Premature labor & 12 & 8.2 \\
Prelabor rupture of membranes & 11 & 7.5 \\
Diabetes & 6 & 4.1 \\
Toxoplasmosis & 4 & 2.8 \\
\hline Total complications* & $\mathbf{1 4 6}$ & $\mathbf{1 0 0}$ \\
\hline
\end{tabular}

Source: Research data.

* There was more than one complication per puerperal woman. 
and Maringá the reference point for realization of the birth is determined and/or advised during the prenatal. The neighboring cities belong to Regional Health Centers of the cities where the university hospitals are located, have health services that are part of the healthcare network for pregnant women, and are responsible for referral when required, and should also guarantee transport to the destination hospital.

Transport by ambulance had a significant relationship with not receiving care at the first hospital sought, which may indicated referral to a service with greater complexity, such as university hospitals. The presence of complications during the current pregnancy may constitute an indicator of gestational risk and, consequently, healthcare with greater complexity. In such cases, small hospitals should refer patients to the reference hospitals.

It was verified that hypertension and urinary tract infections were the most frequent complications during the gestational period and are the main causes of maternal and neonatal morbidity-mortality, culminating in a negative outcome, such as prematurity, near misses (grave maternal morbidity) and death. This fact is in accordance with the literature, which states that urinary tract infection is the most frequent clinical complication during pregnancy and, if not adequately treated, around $25 \%$ of cases may lead to acute pyelonephritis and even induce premature labor, by premature rupture of membranes ${ }^{(10-11)}$. In relation to arterial hypertension, the national report affirms that although these diseases underwent an important reduction between 1990 and 2007 , it is still indicated as a major specific cause of maternal death, with a maternal mortality rate of $15.1 \%{ }^{(3)}$.

Care during birth was associated with both gestational age and weight of the newborn at birth. The estimate fetal weight is undertaken to define the complexity of the care required for cases of low weight or very low weight at birth. With the complementary exams to support the diagnosis, i.e. ultrasound, the evaluation of the weight of the fetus may help to define the care to be rendered to the newborn.

A gestational age of less than 37 weeks and low weight at birth are determinant factors for neonatal morbidity-mortality and estimated survival of the newborn ${ }^{(12,13)}$. Thus, factors such as gestational age and weight at birth probably motivated care not being provided at the first service sought by the pregnant woman, with consequent referral to hospitals with greater capacity for medium and high complexity healthcare.

$70.3 \%$ of the women interviewed had a gestational age of over 37 weeks, and the birth took place at the first hospital sought. When the influence of the place of birth in relation to child mortality was observed, it was verified that premature newborns that required referral to a neonatal ICU at another hospital had a higher percentage of deaths. That is, transport of the pregnant woman to hospitals with neonatal ICUs would be an alternative that reduces child mortality, as speed in providing quality care to the premature newborn is fundamental for a favorable outcome ${ }^{(14)}$. The number of inhabitants in the city is considered as the condition for the existence of neonatal ICU spaces, i.e. the flow of pregnant women with perinatal risks for the larger cities included in this study is comprehensible.

The childbirth period generates anxiety for the parturient woman and her family ${ }^{(15)}$. The need to improve the coordination of prenatal healthcare services with reference to birth and increased coverage are fundamental for reducing the concern of parturient women and their families ${ }^{(4)}$.

Although the Program for Humanization of Prenatal and Birth (PHPN) has the objective of coordinating the network that attends to women during pregnancy, birth and the puerperal period, assuring improvement of access ${ }^{(16)}$, there is still a great challenge in relation to healthcare for women during pregnancy and childbirth in relation to quality itself ${ }^{\left({ }^{17)}\right.}$. Health education for pregnant women improves the quality of care in the gestational period, improves the connection with professionals and health services, contributing to the integrality of the healthcare provided ${ }^{(18)}$.

In this study, despite the results showing that the antepartum "pilgrimage" was configured as referral of those with high-risk pregnancies, demonstrating coordination between the networks in these cities, there was a small number of women that were not adequately referred and needed to seek assistance at other services, in accordance with the reasons reported by puerperal women for not receiving care at the first hospital sought. 


\section{FINAL CONSIDERATIONS}

The results show that residing outside of the city where the university hospital is located, being transported by ambulance and having had some kind of complication during the current pregnancy, observed through both the variable itself as well as the prematurity and low birth weight where determinant factors in receiving healthcare during childbirth at the first service sought. This evidence indicates that women living in other cities and with complications during pregnancy were referred to a reference hospital by the first service sought. The lack of structure at the first service sought by pregnant women and possible prematurity were the main reasons cited by women during interviews as justifications for the difficulty in receiving care during childbirth at the hospitals in their city of origin. Pregnancy with risk to both mother and fetus demands resources and care with higher complexity, with correct and safe referral of the mother required.

It is fundamental for the prenatal and childbirth healthcare network to have a hierarchy that establishes the flow of care in accordance with gestational risk, is dynamic and should reevaluated at any time during the pregnancy-puerperal cycle, prioritizing risk and enabling efficient and fair access.

Some of the limitations of the study include the interviews taking place at university hospitals, where the flow of staff, students and teachers is great, reducing the time available for interviews. The specificities of the Maternity Ward, such as realization of exams, talks, meals and visits, care of newborns and breastfeeding made collection difficult. However, the postpartum period is conducive to better elucidate the real healthcare rendered to parturient women.

\section{REFERENCES}

1 Sanchez RM, Ciconelli RM. Conceitos de acesso à saúde. Rev Panam Salud Pública. 2012;31(3):260-8.

2 Barbastefano PS. O acesso à assistência ao parto para gestantes adolescentes nas maternidades da rede SUS - RJ [dissertação]. Rio de Janeiro (RJ): Faculdade de Enfermagem da Universidade do Estado do Rio de Janeiro; 2009.
3 Presidência da República (BR). Objetivos de desenvolvimento do milênio: $4^{\circ}$ relatório nacional de acompanhamento. Brasília (DF); 2010.

4 Cunha SF, D’Eça Júnior A, Rios CTF, Pestana AL, Mochel EG, Paiva SS. Peregrinação no anteparto em São Luis - Maranhão. Cogitare Enferm. 2010;15(3):441-7.

5 Albuquerque VN, Oliveira QM, Rafael RMR, Teixeira RFC. Um olhar sobre a peregrinação anteparto: reflexões sobre o acesso ao pré-natal. Rev Pesqui Cuid Fundam (Online). 2011;3(2):1935-46.

6 Barbastefano PS, Girianelli VR, Vargens OMC. O acesso à assistência ao parto para parturientes adolescentes nas maternidades da rede SUS. Rev Gaúcha Enferm. 2010;31(4):708-14.

7 Almeida WS, Szwarcwald CL. Mortalidade infantil e acesso geográfico ao parto nos municípios brasileiros. Rev Saúde Pública. 2012;46(1):68-76.

8 Bellato R, Araújo LFS, Castro P. O itinerário terapêutico como uma tecnologia avaliativa da integralidade. In: Pinheiro R, Silva Junior AG, Mattos RA. Atenção básica e integralidade: contribuições para estudos de práticas avaliativas em saúde. Rio de Janeiro: CEPESC-IMS/UERJ-ABRASCO; 2008. $360 \mathrm{p}$.

9 Menezes DC, Leite IC, Schramm JMA, Leal MC. Avaliação da peregrinação anteparto numa amostra de puérperas no município do Rio de Janeiro, Brasil, 1999/2001. Cad. Saúde Pública. 2006;22(3):553-9.

10 Ministério da Saúde (BR), Secretaria de Atenção à Saúde, Departamento de Ações Programáticas Estratégicas, Área Técnica de Saúde da Mulher. Pré-natal e puerpério: atenção qualificada e humanizada - manual técnico. Brasília (DF); 2005.

11 Góis ALC, Cravo EO, Mendes RB. Infecção do trato urinário e trabalho de parto prematuro: a realidade em uma maternidade referência para alto risco em Aracajú (SE). Cad Grad, Ciênc Biol Saúde. 2010;11(11):65-80.

12 Santos HGS, Andrade SM, Silva AMR, Carvalho WO, Mesas AE. Risk factors for infant mortality in a municipality in southern Brazil: a comparison of two cohorts using hierarchical analysis. Cad Saúde Pública. 2012;28(10):1915-26. 
13 Santana IP, Santos JM, Costa JR, Oliveira RR, Orlandi MHF, Mathias TAF. Aspectos da mortalidade infantil, conforme informações da investigação do óbito. Acta Paul Enferm. 2011;24(4):556-62.

14. Araújo BF, et al. Influência do local de nascimento e do transporte sobre a morbimortalidade de recém-nascidos prematuros. J Pediatr. 2011;87(3):257-62.

15 Van der Sand ICP, Girardon-Perlini NMO, Abreu SM. Ansiedade de familiares de parturientes durante o processo de parto. Ciênc Cuid Saúde. 2011;10(3):474-81.
16 Ministério da Saúde (BR), Secretaria de Políticas de Saúde. Programa de humanização no pré-natal e nascimento. Brasília (DF); 2002.

17 Busanello J, Kerber NPC, Fernandes GFM, Zacarias CC, Capellaro J, Silva ME. Humanização do parto e formação dos profissionais da saúde. Ciênc Cuid Saúde. 201 1;10(1):169-75.

18 Souza VB, Roecker S, Marcon SS. Ações educativas durante a assistência pré-natal: percepção de gestantes atendidas na rede básica de Maringá-PR. Rev Eletrôn Enferm [Internet]. 2011;13(2):199-210. Available in: http://www.fen.ufg.br/revista/v13/n2/v13n2a06.htm

\section{Author's address / Endereço do autor / Dirección del autor}

Lorenna Viccentine Coutinho Monteschio

Rua Pioneiro Francisco Alcalde, 666-A, Jardim Higienópolis

87060-373, Maringá, PR

E-mail: helorenn@hotmail.com
Received: 09.05.2013

Approved: 16.12.2013 